\title{
Case Fatality Rate of COVID-19 and Association With Sociodemographic Characteristics of Populations in Ecuador, 2020
}

Karla Flores Sacoto ( $\sim$ drakarla.flores.sacoto@gmail.com )

Paul Sabatier University

Galo Sánchez Del Hierro

Pontificia Universidad Católica del Ecuador

Xavier Jarrín Estupiñan

Hospital Vozandes

Felipe Moreno-Piedrahita Hernandez

Pontificia Universidad Católica del Ecuador

\section{Research Article}

Keywords: case-fatality rate, COVID-19, sociodemographic characteristics.

Posted Date: May 10th, 2021

DOI: https://doi.org/10.21203/rs.3.rs-444898/v1

License: (c) (i) This work is licensed under a Creative Commons Attribution 4.0 International License. Read Full License 


\section{Abstract \\ Background}

COVID-19 has caused deaths worldwide affecting the most vulnerable population with different case fatality rates. Socioeconomic conditions have demonstrated a role regarding the spread of infections and mortality. Socioeconomic characteristics of Ecuador related to poverty, ethnicity and demographic characteristics increase the impact of COVID-19 in certain populations.

\section{Methods}

\section{Objective}

To analyze the influence of demographic factors on the COVID-19 case fatality rate (CFR) in Ecuador. Design: cross sectional study. Setting 24 provinces in Ecuador-221 cantons. Population: data including 233.277 confirmed COVID-19 cases of Ecuador. Primary and secondary outcome measures COVID-19 CFR and crude cause-specific death rate weight calculated using province-country level data from health ministry of Ecuador in data website.

\section{Results}

Ecuadors CFR is $4,03 \%$, analyzed by cantons the CFR increases to a median of $5,75 \%$, with cantons like Playas with a CFR of $32,39 \%$. The morbidity rate has a median of 795,31 per 100000 hab. with the highest rate in Isabela-Galápagos $(10185,49)$, Aguarico-Orellana $(9506,75)$ and Baños-Tungurahua $(4156,85)$. And the crude COVID-19 death rate has a median of 39,73 per 100 000 hab. with the highest rate in Penipe-Chimborazo $(201,29), 24$ de Mayo-Manabí $(143,79)$ and San Pedro de Huaca-Carchi $(134,36)$. The correlations show relations with sociodemographic factors like poverty, ethnicity and scholarity.

\section{Conclusion}

The CFR is the proxy indicator of COVID-19 impact in Ecuador and the analysis made by location give us new information about the specific impact of this disease.

\section{Background}

SARS-CoV-2 virus identified as the cause of COVID-19, declared a pandemic since march 11, 2020(1); the virus was first identified in Wuhan, of the Hubei province in China, in December 2019, and become a major concern worldwide(2) .

COVID-19 is knows as a respiratory disease with rapid spread whose etiological agent is an RNA virus related to the coronavirus family; it remains unknown which animal is the intermediary host(3). The reproduction rate of SARS-CoV-2 has a $\mathrm{R}$ between 2,4 and $3,3(4,5)$, the most frequent symptoms are fever, cough and dyspnea(6).

According to the data collected towards the COVID-19 the information updated at march 15, 2021 shows a cumulative global cases of 119.956 .955 people infected by the virus over 192 countries with 2.655 .280 global deaths worldwide(7). The estimated global CFR is around 2,17\%(7). In Latin America and the Caribbean the first case reported was in Sao Paulo, Brazil 25 February 2020.

The epidemiological presentation of COVID-19 is dynamic and changes over time; the most affected region at the beginning was Asia; nowadays, America is leading the chart, with US as the first country followed by Brazil; and becoming the region most affected of COVID-19(8).

On 2020, 232.370 cases of COVID-19 were identified in Ecuador and involved people from all 24 provinces of the country with severe cases of pneumonia due to SARS-CoV2 (severe acute respiratory syndrome coronavirus 2). On February 29, 2020 the first case of COVID-19 was reported; and Ecuador was the third country of the region to confirm a case(9). The first provinces to report 
positive cases were Clusters of patients with COVID-19 located on the coast of Ecuador, a substantial number of critically ill patients were diagnosed. Since then, the number of cases identified had rapidly increased, mainly in Pichincha (Andean region), Guayas and Manabí (Coast region).

\section{Epidemiological surveillance}

Ecuador is the eighth country in Latin America of COVID-19 cases(10), and also has a very high case-fatality rate. The case fatality rate is a health proportion that relates the population with a disease and the deaths caused by the disease during an specific period of time; it is used to measure the impact of the disease on the population, and it has been used to evaluate COVID-19 impact as an epidemiological indicator(11). There is lack of published studies of country-level demographic characteristics on COVID-19 fatality rates. This article reviews the Ecuadorian experience with COVID-19 with emphasis on fatalities by location.

Socioeconomic conditions have demonstrated a role regarding the spread of infections and the impact on job loss, poverty increase and economic crisis. Our study concentrates on the statistical analyzes of the association between COVID-19 CFR and socioeconomic indicators.

The Republic of Ecuador is a country located in South-America, covers $276840 \mathrm{~km} 2$ and its borders are Colombia and Peru. Composed by 3 continental regions: Andean, Coast, and Amazonia and one Insular region; Ecuador is divided by 24 provinces formed by smaller political divisions called cantons.

During COVID-19 pandemic a wide range of public health studies have been published, the factors that affects spread of the virus is one of the critical characteristics of COVID-19 that relays on the epidemic mechanism, mobility, and management strategies. Epidemiological statistical analysis is frequently used to show the correlations patterns of infectious diseases and environmental qualities of the population to identify clusters and prevent potential spreads(12-15).

An infectious disease surveillance is considered as a public health method that detects important risks and it is used to inform the planning of public health interventions or further investigations. At the outset of COVID-19 outbreak, the Ministry of Health (MSP) applied a surveillance system to collect information on all people with COVID-19 throughout the country according to the guidelines published by the World Health Organization (WHO) on January 30, 2020. The Emergency Committee-WHO declared that the 2019$\mathrm{nCoV}$ is a PHEIC (Public Health Emergency of International Concern) so the MSP introduce in the national surveillance thorough the investigation chart "EPI 1".

Data on all COVID-19 cases were obtained from all 24 Ecuadorian provinces. COVID-19 cases were identified by reverse transcriptase-polymerase chain reaction (RT-PCR) $(16,17)$. The fatality rate was defined as number of deaths in person who tested positive for SARS-CoV-2 divided by number of SARS-CoV-2 cases(18). The overall fatality rate of persons with confirmed COVID-19 in the Ecuadorian population (accessed: March 14, 2021), was 6,16\% (14.371/233.227 cases). This rate is higher than observed in other countries of the region like Perú $(3,3 \%)$, Brazil $(2,6 \%)$, Panamá $(1,7 \%)$ and Colombia $(2,6 \%)$ and the factors related to this data needs to be further studied.

\section{Methods}

\section{Data on COVID-19 - Ecuador (MSP) and literature search}

The COVID-19 dataset used in this study was downloaded from the web page:

https://public.tableau.com/profile/direcci.n.nacional.de.vigilancia.epidemiol.gica.msp\#!/vizhome/COVID19ecu_MSP_DNVE/COVID$19 \mathrm{MSP}$, accessed on march 13, 2021; which is a data maintained by the organization: MSP- Dirección Nacional de Vigilancia Epidemiológica and updated daily. The dataset contents country level data on confirmed cases, deaths, and testings. The data from sociodemographic indicators was downloaded from the Instituto Nacional de Estadisticas y Censos" (INEC) from the last national survey done on 2010.

We conducted a systematic literature research of online databases, the terms and relative varinas were as follows: COVID-19, 2019nCoV; fatality rate. We also reviewed references included on articles for guaranteeing comprehension and accuracy of the data 
collected.

\section{Data extraction and quality assessment - Epidemiological rates}

Data extraction and evaluation of literature quality were managed independently by two investigators (F.K and J.X). Microsoft Excel database was used to saved available information, including demographic data. The case fatality rate of COVID-19 was calculated as the number of total deaths due to COVID-19 divided by the number of total confirmed COVID-19 cases of year 2020, accessed on march 13 2021, multiplied by 100. It was calculated in this study as it might reflect the severity of COVID-19 and it is an indirect measure of the efficiency of healthcare response(19).

The morbidity rate of COVID-19 was calculated as the number of confirmed COVID-19 cases till December 31, 2020 divided by the total population multiplied by 100.000 .

The crude cause-specific death rate of COVID-19 was calculated as the number of total deaths due to COVID-19 till December 31,2020 divided by the total population multiplied by $100.000(20)$, this epidemiological rates shows the impact of COVID-19 on the general population.

\section{Statistical analysis of data}

Microsoft Excel was used to calculate rates; SPSS 22.0 software was used to perform statistical analysis. The distribution had a $p$ $<0,001$ and the inferential analysis was made using Spearman correlation and Kruskall-Wallis.

\section{Results}

\section{Descriptive characteristics of the variables}

In total, 232.370 confirmed COVID-19 cases and 10.293 deaths from 24 provinces of Ecuador from Mars to December 2020 were included. A total population of 17468 736. The national CFR calculated is 5,74\% ( $\mathrm{Mdn}=4,04$; Range $=32,39)$ with a morbidity rate of $1172,63(\mathrm{Mdn}=795,31$; Range $=10$ 095,49); the average of confirmed cases by canton is 1051,45 . The descriptive statistics of the 221 cantons by regions of the variables analyzed are shown in Table 1.

The provinces with the highest CFR are Santa Elena $(14,04 \%)$, Chimborazo $(12,02)$ and Guayas $(9,89)$, the highest morbidity rate are in Galápagos $(5099,47)$, Orellana $(3045,79)$ and Pastaza $(2448,73)$ and the highest crude mortality rate are in the provinces of Santa Elena (102,54), Manabí $(86,55)$ and Carchi $(86,25)$.

Table 1

Descriptive statistics

\begin{tabular}{|c|c|c|c|}
\hline & $\begin{array}{l}\text { Fatality rate } \\
(\%)\end{array}$ & $\begin{array}{l}\text { Attack rate } \\
(x 1000)\end{array}$ & $\begin{array}{l}\text { Crude Mortality rate } \\
(x 100000)\end{array}$ \\
\hline Amazonic (41) & $1,82^{*}(\mathrm{DE} \pm 1,95)$ & $14,91^{\star \star \star}(\mathrm{DE} \pm 14,99)$ & $27,96(\mathrm{DE} \pm 25,85)$ \\
\hline Coast (84) & $8,26^{*}(\mathrm{DE} \pm 5,08)$ & $5,92^{\star \star \star}(\mathrm{DE} \pm 5,36)$ & $48,02^{\star \star \star}(\mathrm{DE} \pm 36,29)$ \\
\hline Insular (3) & $0,63(\mathrm{DE} \pm 0,67)$ & $31,47^{\star \star \star}(\mathrm{DE} \pm 44,44)$ & $31,03(\mathrm{DE} \pm 7,01)$ \\
\hline Andean (93) & $3,53^{\star \star \star}(\mathrm{DE} \pm 4,17)$ & $9,32^{\star \star \star}(\mathrm{DE} \pm 8,00)$ & $33,46^{\star \star \star}(\mathrm{DE} \pm 32,11)$ \\
\hline \multicolumn{4}{|c|}{ Kolmogorov-Smirnov * $p<0,05 ; * \star p<0,01 ; * \star \star p<0.001$} \\
\hline
\end{tabular}

The variables calculated have an asymmetrical distribution, the analysis of variance shows that the highest variability is in morbidity rate, all calculated rates have positive asymmetry with leptocurtosis.

\section{Fatality rate gender and population age}


Ecuador has reported different case fatality ratios between different population age and gender. The Table 2 shows the age-specific fatality rate in Ecuador. The highest case fatality rate is among people $>65$ years old $(29,09 \%)$, being higher in male $(34,65 \%)$. It calls the attention that the third position is in the group population less than 1 year old with a $3,73 \%$ of CFR (Table 2).

Table 2

Case fatality rate by age and gender in Ecuador, 2020

\begin{tabular}{|c|c|c|c|c|c|c|}
\hline & \multicolumn{6}{|l|}{ Ecuador } \\
\hline & \multicolumn{2}{|l|}{ Total } & \multicolumn{2}{|l|}{ Female } & \multicolumn{2}{|l|}{ Male } \\
\hline & $\begin{array}{l}\text { No. of deaths (\% } \\
\text { of total) }\end{array}$ & $\begin{array}{l}\text { Case-fatality } \\
\text { rate, \% }\end{array}$ & $\begin{array}{l}\text { No. of deaths (\% } \\
\text { of total) }\end{array}$ & $\begin{array}{l}\text { Case-fatality } \\
\text { rate, \% }\end{array}$ & $\begin{array}{l}\text { No. of deaths (\% } \\
\text { of total) }\end{array}$ & $\begin{array}{l}\text { Case-fatality } \\
\text { rate, \% }\end{array}$ \\
\hline All & 14371 & 6,16 & $4817(33,52)$ & 4,35 & $9554(66,48)$ & 7,79 \\
\hline \multicolumn{7}{|c|}{$\begin{array}{l}\text { Age } \\
\text { groups, y }\end{array}$} \\
\hline 0 & $18(0,13)$ & 4,02 & $9(0,19)$ & 4,35 & $9(0,09)$ & 3,73 \\
\hline $1-4$ & $11(0,08)$ & 1,06 & $6(0,13)$ & 1,24 & $5(0,05)$ & 0,89 \\
\hline $5-9$ & $12(0,08)$ & 0,64 & $6(0,13)$ & 0,64 & $6(0,06)$ & 0,64 \\
\hline $10-14$ & $9(0,06)$ & 0,27 & $3(0,06)$ & 0,18 & $6(0,06)$ & 0,35 \\
\hline $15-19$ & $17(0,12)$ & 0,25 & $12(0,25)$ & 0,33 & $5(0,05)$ & 0,15 \\
\hline $20-49$ & $1401(9,75)$ & 0,99 & $426(8,85)$ & 0,63 & $975(10,21)$ & 1,31 \\
\hline $50-64$ & $4087(28,44)$ & 8,63 & $1252(25,99)$ & 5,56 & $2835(29,67)$ & 11,41 \\
\hline$\geq 65$ & $8816(61,35)$ & 29,09 & $3103(64,41)$ & 22,45 & $5713(59,8)$ & 34,65 \\
\hline
\end{tabular}

\section{COVID-19 case-fatality rate distribution}

A total of 221 cantons were included with 10.293 deaths and a fatality rate of 4,43\%. The results of distribution of COVID-19 casefatality rate of the 221 cantons is shown in Fig. 1. The mean and median case fatality rate are 5,75\% and 4,04\% respectively (Table 1), with the highest rate is in Playas-Guayas (32,39\%), Colta-Chimborazo (25,33\%) and Coronel Marcelino Maridueña-Guayas (22,23\%), Guamote (18,48\%) and Penipe (16,67\%) (Fig. 1).

The cantons that had a CFR above 5,74\% were 85 (38,5\%), from the total of cantons 62 (72,9\%) are located at the coast, 21 (24,7\%) are located at the Andean region and $2(2,4 \%)$ belong to the amazonic region. The Insular region showed a CFR less than the average.

Of the provinces with a CFR above the average the number of cantons that have a highest CFR are: 3 cantons in Santa Elena (100\%), 20 cantons in Manabí (90,9\%), 10 cantons in Los Ríos (76,9\%), 19 cantons in Guayas (76\%) and 7 cantons in Chimborazo (70\%).

The correlation results between CFR and hovel housing type were moderate with a value of rho(219) $=.517, \mathrm{p}=<.001$ (Table 3 ) 
Table 3

Correlations with sociodemographic characteristics and CFR

\begin{tabular}{|c|c|c|}
\hline & & $\begin{array}{l}\text { Correlation Coefficient } \\
\mathrm{rho}_{(219)}\end{array}$ \\
\hline \multirow[t]{7}{*}{ Sociodemographic } & Average people/house & $-0,127$ \\
\hline & Population density & $0,437 * \star \star$ \\
\hline & Average scholarity (ys) & $-0,134^{*}$ \\
\hline & Rural \% & $-0,171^{*}$ \\
\hline & Poverty \% & $0,224 * \star$ \\
\hline & Economically inactive population \% & $0,362 * \star \star$ \\
\hline & Illiterate \% & $0,214^{\star *}$ \\
\hline \multirow[t]{4}{*}{ Ethnicity (\%) } & Indigenous \% & 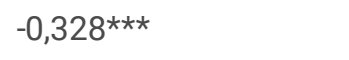 \\
\hline & Afroecuadorian \% & $0,289 * * *$ \\
\hline & Montubia \% & $0,452 * \star \star$ \\
\hline & Mestizo \% & $-0,16^{\star \star}$ \\
\hline \multirow[t]{8}{*}{ Housing type (\%) } & House & $-0,168^{*}$ \\
\hline & Appartment & 0,012 \\
\hline & Room & $-0,166^{*}$ \\
\hline & Mediagua & $-0,044$ \\
\hline & Ranch & $0,238 * \star \star$ \\
\hline & Hovel & $0,517 * \star \star$ \\
\hline & Hut & 0,116 \\
\hline & Other housing & 0,1 \\
\hline \multirow[t]{11}{*}{ Scholarity (\%) } & None & $0,238 * \star *$ \\
\hline & Alfabethization center & $0,142^{*}$ \\
\hline & Preschool & $0,247 \star \star \star$ \\
\hline & Primary school & 0,124 \\
\hline & Highschool & $0,188^{*}$ \\
\hline & Basic education & 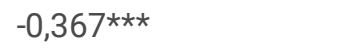 \\
\hline & Bachillerato & $-0,381^{\star \star \star}$ \\
\hline & Post bachillerato & $-0,172^{\star}$ \\
\hline & College & $-0,022$ \\
\hline & Postgraduate & $-0,082$ \\
\hline & Not known & $0,215^{\star \star}$ \\
\hline \multirow[t]{2}{*}{ Insurance type (\%) } & With insurance & $-0,292^{\star \star \star}$ \\
\hline & Without insurance & $0,243^{\star \star \star}$ \\
\hline
\end{tabular}

Source: Prepared by the authors for the present investigation. 


\begin{tabular}{|c|c|c|}
\hline & & $\begin{array}{l}\text { Correlation Coefficient } \\
\mathrm{rho}_{(219)}\end{array}$ \\
\hline \multirow[t]{8}{*}{ Basic Services acess (\%) } & Drinking water & $-0,173^{\star \star}$ \\
\hline & No electricity & 0,034 \\
\hline & Garbage management & 0,011 \\
\hline & Excretal disposal & $-0,218 * \star$ \\
\hline & Computer & $-0,356 * \star \star$ \\
\hline & Conventional phone & $-0,349 \star \star \star$ \\
\hline & Mobile service & 0,087 \\
\hline & Internet service & 0,009 \\
\hline \multicolumn{3}{|c|}{$\star p<.05 ; * \star p<.01 ; * \star * p<.001$} \\
\hline
\end{tabular}

\section{Crude COVID-19 death rate}

Distribution of crude COVID-19 death rate of the 221 cantons is shown in Fig. 2, 61 cantons have a Crude COVID-19 death rate above 58,92 (27,6\%)(Fig. 2). The most affected region is the coast with 28 cantons (45,9\%), followed by the Andean region with 24 cantons $(39,3 \%)$ and the amazonic region with 9 cantons $(14,8 \%)$.

The distribution of proportions by provinces are Santa Elena 3 cantons (100\%), Santo Domingo de los Tsáchilas 2 cantons (100\%), Carchi 5 cantons (83,3\%), Manabí 15 cantons (68,2\%) and Napo with 3 cantons $(60 \%)$.

The mean and median crude death rate are 46,09 cases per 100.000 and 39,72 cases per 100.000 respectively (Table 1 ), with the highest rate in Penipe-Chimborazo (201,29), 24 de Mayo-Manabí $(143,79)$, San Pedro de Huaca-Carchi $(134,36)$, Playas-Guayas $(134,17)$ and Rocafuerte -Manabí $(134,01)$.

The 28 cantons with the highest crude mortality rate of the coast represent the $33,3 \%$ of the region, the 24 cantons of the Andean region represent the $25,8 \%$ and the 9 cantons of amazonic region are the $22 \%$ of the region.

\section{Discussion}

The overall case fatality rate calculated in Ecuador (4,43\%) till December 2020 is substantially higher than in other countries of the region and higher than the worldwide case fatality(21). When data were stratified by age group, the case- fatality rate in Ecuador appear very similar for age groups 1 to 19 years, but rates are higher in Ecuador among male individuals aged 50 or older; also in the population less than 1 year old. The distribution of cases is extremely different analyzed by gender with a higher infection rate on males than females. The cause of perceived reduced susceptibility of females needs further investigation in order to improve protective measures.

The demographic characteristics of the Ecuadorian population differ from other countries. By 2020 , approximately $8 \%$ of the Ecuadorian population was aged 65 years or older(22). COVID-19 has proved to have higher rates of mortality in older patients, in Ecuador. The epidemiological analysis shows that males have a higher fatality rate compared by gender as seen in the study of Long-quan et al, the reason for it requires further investigation(23).

COVID-19 fatality rates are challenging to assess with certainty; data from China, United Kingdom and Italy report a death rate around 0,7 to $1,3 \%(21,24-26)$.

One of the best ways to know the impact of COVID-19 is mortality. Mortality has a wide variability among each country that probably depends on the health system response regarding effectiveness on testing policies, health system capacity and efficacy of

Page $7 / 14$ 
response to health emergencies(27). During the first reports made by Long-quan et al. the fatality rate among 1994 patients with COVID-19 was $5 \%(95 \% \mathrm{CI}[0.01,0.11])(23)$.

The worldwide mortality rate is $3 \%$. Salzberger el al. found a case fatality rate of $1,38 \%$ with their modell(28). However, this rate varies between countries (China:2,3; South Korea: 2,3; Italy: 13,1) related to population average age, age distribution and the health system capacity on diagnosis and epidemiological surveillance(21).

The mortality risk of COVID-19 shows higher rates related to aging; in China the mortality rate was less than $0,5 \%$ in patients younger than 50 years increasing to $16 \%$ in patients older than 80 years $(6,29-31)$. Elder patients, above 60 years show higher susceptibility to life-threatening complications derived from $\operatorname{COVID-19}(32,33)$.

Dong et al describe that children have a clinical progression and disease severity different from adults, as $90 \%$ have a mild or moderate disease; those who develop severe disease show having comorbidities that increase the mortality rate (34-36).

The CFR is not a constant epidemiological measure and it varies between populations, over time and it is modified by external factors like environment, treatments and quality of health care system(37). To report a worldwide CFR evolves multiple factors that need to be taken care of. Firstly, the capacity to diagnose due to the lack of sufficient laboratory test for COVID-19 patients. Secondly, the hessite of some COVID-19 patients to report their illness to the health system; the real values are difficult to get, and the data collection affects the fatality rate calculation(38).

In Italy the mortality was higher in patients aged 70-89(39), in Ecuador the highest mortality was around the same age but differs on the group of less than 1 year were the CFR is 4,02 .

The highest rate of morbidity could be related to the surveillance strategy used in Ecuador, as the COVID-19 test are made only in symptomatic patients without the identification of patients with mild symptoms(38).

Regarding the preventive measures practice Bates et al. applied a binomial regression analysis which suggests that unemployed individuals, househusbands/housewives, or manual laborers, and individuals with elementary scholarity have lower levels of knowledge regarding COVID-19 which supports the correlation found between illiteracy and CFR by cantons and might be related to the access to official information about COVID-19(40).

During the early periods of COVID-19 in Ecuador Ortiz-Prado et al. found that men were at a higher risk of dying from COVID-19 and also it was higher in older individuals and the presence of comorbidities, as our study found the same relation regarding the sex and age(41).

Bolaño-Ortiz et al. found that the spread of COVID-19 through Latin America and the Caribbean region shows a correlation with socioeconomic indexes(42), the same correlation that we found in our study, the variables of poverty levels suggest that inequality is related to the spread of COVID-19.

Shammi et al. found a correlation of COVID-19 cases and deaths with economic indicators showing a significant correlation in between the urban poverty rate $(r=-0.77 ; p=0.01)$ and the urban extreme poverty rate $(r=-0.79 ; p=0.01)$, low poverty rates were related to higher rates of COVID-19 infection; explained by the people who have informal jobs in countries with lower Gini index values(43). It appears that there is a relation with inequality and heterogeneity in populations; Biggs et al. studied the impact on income level, inequality and poverty, health status depends on wealth distribution(44).

Poverty has proven to be a potential risk for COVID-19 and the incidence of infectious diseases are related to socioeconomic, environmental, and ecological aspects(45-47).

Education level, family income, occupation, ethnic and number of people living in a house have been considered socioeconomic factors with disparities in hospitalization for COVID-19(48).

\section{Conclusions}


In conclusion, the current data illustrates that Ecuador has a high morbidity and mortality rate of older patients with confirmed COVID-19 infection and that male population in Ecuador are more affected $(1,98: 1)$.

Within Ecuador, COVID-19 deaths mainly observed among older, male patients. The increase in the number of infected patients reflects a lack of medical resources.

However, these data are limited and were derived from the first year of documented COVID-19 cases in Ecuador; a more extensive and large-scale studies are required to identify factors related to fatality rate.

From a scientific perspective, the comparisons discussed highlight the need for transparency in reporting cases policies, with clear reporting of the denominators used to calculate case-fatality rates and the age, sex and location status of affected persons when comparing COVID-19 cases and mortality rates between different regions.

This is an important information for governments and non-governmental organizations to identify characteristics that are associated with high fatality rates to develop specific measures to prevent or intervene during this health crisis and diminish the consequences related to the burden of this disease.

This study has shown some relations between sociodemographic factors with mortality caused by COVID-19 at different levels which can guide policymakers to control and prevent the COVID-19 outbreaks(49-51).

\section{Declarations}

\section{Ethics approval and consent to participate}

Not applicable

\section{Consent for publication}

Not applicable

\section{Availability of data and materials}

The datasets analysed during the current study are available in the Tableau Public- Dirección de vigilancia epidemiológica repository, https://public.tableau.com/profile/direcci.n.nacional.de.vigilancia.epidemiol.gica.msp\#!/vizhome/COVID19ecu_MSP_DNVE/COVID$19 \mathrm{MSP}$

\section{Competing interests}

The authors declare that they have no competing interests.

\section{Funding}

Financial assistance: Solidarity Fund for Innovative Projects (FSPI)

\section{Authors' contributions}

\begin{tabular}{ll} 
KMFS & Major contribution, statistical analyze \\
\hline GASDH & Guidance, discussion \\
\hline JXJE & Statistical analyze \\
\hline FGMPH & Dicussion
\end{tabular}

\section{Acknowledgements}


Emmanuelle Rial-Sebbag

Santiago Fernando Burneo Nuñez

\section{References}

1. Organización Mundial de Salud. OPS/OMS | La OMS caracteriza a COVID-19 como una pandemia [Internet]. OMS. 2020 [cited 2020 Jun 19]. Available from: https://www.paho.org/hq/index.php?option=com_content\&view=article\&id=15756:whocharacterizes-covid-19-as-a-pandemic\&ltemid=1926\&lang=es

2. Margallo II LN, Diaz M, Lim PP. 2019 Novel Coronavirus Pandemic: What Do We Know? South Dakota Med. 2020;73(6).

3. Lu R, Zhao X, Li J, Niu P, Yang B, Wu H, et al. Genomic characterisation and epidemiology of 2019 novel coronavirus: implications for virus origins and receptor binding. Lancet (London, England). 2020 Feb;395(10224):565-74.

4. Peiris JSM, Guan Y, Yuen KY. Severe acute respiratory syndrome. Nat Med. 2004 Dec;10(12 Suppl):S88-97.

5. Zhu N, Zhang D, Wang W, Li X, Yang B, Song J, et al. A Novel Coronavirus from Patients with Pneumonia in China, 2019. N Engl J Med. 2020 Feb;382(8):727-33.

6. Xu X-W, Wu X-X, Jiang X-G, Xu K-J, Ying L-J, Ma C-L, et al. Clinical findings in a group of patients infected with the 2019 novel coronavirus (SARS-Cov-2) outside of Wuhan, China: retrospective case series. BMJ. 2020 Feb;368:m606.

7. (i) JHU of M. Mortality Analyses - Johns Hopkins Coronavirus Resource Center [Internet]. 2021 [cited 2021 Mar 15]. Available from: https://coronavirus.jhu.edu/data/mortality

8. Simbana-Rivera K, Gomez-Barreno L, Guerrero J, Simbana-Guaycha F, Fernandez R, Lopez-Cortes A, et al. Interim analysis of pandemic Coronavirus disease 2019 (COVID-19) and the SARS-CoV-2 virus in Latin America and the Caribbean: morbidity, mortality and molecular testing trends in the region. MedRxiv. 2020;

9. Actualización de casos de coronavirus en Ecuador - Ministerio de Salud Pública [Internet]. [cited 2021 Mar 15]. Available from: https://www.salud.gob.ec/actualizacion-de-casos-de-coronavirus-en-ecuador/

10. Statista. Muertes por COVID19 en América Latina y el Caribe | Statista [Internet]. 2021 [cited 2021 Mar 15]. Available from: https://es.statista.com/estadisticas/1105336/covid-19-numero-fallecidos-america-latina-caribe/

11. Jabbar SI. Automated analysis of fatality rates for COVID 19 across different countries. Alexandria Eng J. 2021 Feb 1;60(1):521-6.

12. Gross B, Zheng Z, Liu S, Chen X, Sela A, Li J, et al. Spatio-temporal propagation of COVID-19 pandemics. EPL (Europhysics Lett. 2020;131(5):58003.

13. Lawson AB. Bayesian disease mapping: hierarchical modeling in spatial epidemiology. CRC press; 2018.

14. Zulu LC, Kalipeni E, Johannes E. Analyzing spatial clustering and the spatiotemporal nature and trends of HIV/AIDS prevalence using GIS: the case of Malawi, 1994-2010. BMC Infect Dis [Internet]. 2014;14(1):285. Available from: https://doi.org/10.1186/1471-2334-14-285

15. Anselin L, Syabri I, Kho Y. GeoDa: An Introduction to Spatial Data Analysis. Geogr Anal [Internet]. 2006 Jan 1 [cited 2021 Mar 15];38(1):5-22. Available from: http://doi.wiley.com/10.1111/j.0016-7363.2005.00671.x

16. Drosten C, Günther S, Preiser W, van der Werf S, Brodt H-R, Becker S, et al. Identification of a novel coronavirus in patients with severe acute respiratory syndrome. N Engl J Med. 2003 May;348(20):1967-76.

17. Corman VM, Müller MA, Costabel U, Timm J, Binger T, Meyer B, et al. Assays for laboratory confirmation of novel human coronavirus (hCoV-EMC) infections. Euro Surveill Bull Eur sur les Mal Transm = Eur Commun Dis Bull. 2012 Dec;17(49).

18. Porta M. A dictionary of epidemiology. Oxford university press; 2014.

19. Britannica. case fatality rate | Definition, Example, Equation, \& Facts | Britannica [Internet]. [cited 2021 Mar 15]. Available from: https://www.britannica.com/science/case-fatality-rate

20. Britannica. Epidemiology - Basic concepts and tools | Britannica [Internet]. [cited 2021 Mar 15]. Available from: https://www.britannica.com/science/epidemiology/Basic-concepts-and-tools

21. Onder G, Rezza G, Brusaferro S. Case-Fatality Rate and Characteristics of Patients Dying in Relation to COVID-19 in Italy. JAMA [Internet]. 2020 May 12;323(18):1775-6. Available from: https://doi.org/10.1001/jama.2020.4683 
22. Instituto Nacional de Estadisticas y Censos. Censo de poblacion y vivienda 2010 [Internet]. Quito; 2012. Available from: http://redatam.inec.gob.ec/cgibin/RpWebEngine.exe/PortalAction?\&MODE=MAIN\&BASE=CPV2010\&MAIN=WebServerMain.inl

23. Li L, Huang T, Wang Y, Wang Z, Liang Y, Huang T, et al. COVID-19 patients' clinical characteristics, discharge rate, and fatality rate of meta-analysis. J Med Virol. 2020;92(6):577-83.

24. Jordan RE, Adab P, Cheng K. Covid-19: risk factors for severe disease and death. British Medical Journal Publishing Group; 2020.

25. World meters. World meters [Internet]. 2020. 2020 [cited 2020 Jul 15]. Available from: https://www.worldometers.info/coronavirus/

26. Russell TW, Hellewell J, Jarvis Cl, van Zandvoort K, Abbott S, Ratnayake R, et al. Estimating the infection and case fatality ratio for coronavirus disease (COVID-19) using age-adjusted data from the outbreak on the Diamond Princess cruise ship, February 2020. Eurosurveillance [Internet]. 2020;25(12). Available from: https://www.eurosurveillance.org/content/10.2807/15607917.ES.2020.25.12.2000256

27. Rajgor DD, Lee MH, Archuleta S, Bagdasarian N, Quek SC. The many estimates of the COVID-19 case fatality rate [Internet]. Vol. 20, The Lancet Infectious Diseases. Lancet Publishing Group; 2020 [cited 2021 Mar 15]. p. 776-7. Available from: https://doi.org/10.1016/S1473-

28. Salzberger B, Buder F, Lampl B, Ehrenstein B, Hitzenbichler F, Hanses F. Epidemiology of SARS-CoV-2 infection and COVID-19. Internist. 2020 Aug 1;61(8):782-8.

29. Zhi Z xin xue guan bing za. Expert consensus on principal of clinical management of patients with severe emergent cardiovascular diseases during the epidemic period of COVID-19. Assoc Chinese Soc Cardiol Chinese Med. 2020;48(3):189-94.

30. Zhang J, Wang X, Jia X, Li J, Hu K, Chen G, et al. Risk factors for disease severity, unimprovement, and mortality in COVID-19 patients in Wuhan, China. Clin Microbiol Infect Off Publ Eur Soc Clin Microbiol Infect Dis. 2020 Jun;26(6):767-72.

31. Zhou F, Yu T, Du R, Fan G, Liu Y, Liu Z, et al. Clinical course and risk factors for mortality of adult inpatients with COVID-19 in Wuhan, China: a retrospective cohort study. Lancet [Internet]. 2020 Mar;395(10229):1054-62. Available from: https://linkinghub.elsevier.com/retrieve/pii/S0140673620305663

32. Murthy S, Gomersall CD, Fowler RA. Care for Critically III Patients With COVID-19. JAMA. 2020 Apr;323(15):1499-500.

33. Yang X, Yu Y, Xu J, Shu H, Xia J, Liu H, et al. Clinical course and outcomes of critically ill patients with SARS-CoV-2 pneumonia in Wuhan, China: a single-centered, retrospective, observational study. Lancet Respir Med. 2020 May;8(5):475-81.

34. Dong Y, Mo X, Hu Y. Epidemiological Characteristics of 2143 Pediatric Patients With 2019 Coronavirus Disease in China. Mar 18. 2020;

35. Gu H, Xie Z, Li T, Zhang S, Lai C, Zhu P, et al. Angiotensin-converting enzyme 2 inhibits lung injury induced by respiratory syncytial virus. Sci Rep. 2016 Jan;6:19840.

36. Xia W, Shao J, Guo Y, Peng X, Li Z, Hu D. Clinical and CT features in pediatric patients with COVID-19 infection: Different points from adults. Pediatr Pulmonol. 2020 May;55(5):1169-74.

37. Rebecca Harrington. Case fatality rate. Encyclopedia Britannica. [Internet]. https://www.britannica.com/science/case-fatalityrate. 2020 [cited 2021 Apr 7]. Available from: https://www.britannica.com/science/case-fatality-rate

38. Cañizares Fuentes R, Aroca R, Blasco Carlos M. Evaluation of COVID-19 Surveillance Strategy in Ecuador. Disaster Med Public Health Prep. 2020 Sep;1-4.

39. Remuzzi A, Remuzzi G. COVID-19 and Italy: what next? [Internet]. Vol. 395, The Lancet. Lancet Publishing Group; 2020 [cited 2021 Apr 7]. p. 1225-8. Available from: http://www.salute.gov.it/

40. Bates BR, Moncayo AL, Costales JA, Herrera-Cespedes CA, Grijalva MJ. Knowledge, Attitudes, and Practices Towards COVID-19 Among Ecuadorians During the Outbreak: An Online Cross-Sectional Survey. J Community Health. 2020 Dec;45(6):1158-67.

41. Ortiz-Prado E, Simbaña-Rivera K, Barreno LG, Diaz AM, Barreto A, Moyano C, et al. Epidemiological, socio-demographic and clinical features of the early phase of the COVID-19 epidemic in Ecuador. Brookes VJ, editor. PLoS Negl Trop Dis [Internet]. 2021 Jan 4 [cited 2021 Apr 7];15(1):e0008958. Available from: https://dx.plos.org/10.1371/journal.pntd.0008958

42. Bolaño-Ortiz TR, Camargo-Caicedo Y, Puliafito SE, Ruggeri MF, Bolaño-Diaz S, Pascual-Flores R, et al. Spread of SARS-CoV-2 through Latin America and the Caribbean region: A look from its economic conditions, climate and air pollution indicators. 
Environ Res [Internet]. 2020;191:109938. Available from:

https://www.sciencedirect.com/science/article/pii/S0013935120308331

43. Shammi M, Bodrud-Doza M, Towfiqul Islam ARM, Rahman MM. COVID-19 pandemic, socioeconomic crisis and human stress in resource-limited settings: A case from Bangladesh. Heliyon [Internet]. 2020;6(5):e04063. Available from: https://www.sciencedirect.com/science/article/pii/S2405844020309075

44. Biggs B, King L, Basu S, Stuckler D. Is wealthier always healthier? The impact of national income level, inequality, and poverty on public health in Latin America. Soc Sci Med [Internet]. 2010;71(2):266-73. Available from: https://www.sciencedirect.com/science/article/pii/S0277953610003047

45. Jones KE, Patel NG, Levy MA, Storeygard A, Balk D, Gittleman JL, et al. Global trends in emerging infectious diseases. Nature [Internet]. 2008;451(7181):990-3. Available from: https://doi.org/10.1038/nature06536

46. Morens DM, Folkers GK, Fauci AS. The challenge of emerging and re-emerging infectious diseases. Nature [Internet]. 2004;430(6996):242-9. Available from: https://doi.org/10.1038/nature02759

47. Anser MK, Yousaf Z, Khan MA, Nassani AA, Alotaibi SM, Qazi Abro MM, et al. Does communicable diseases (including COVID19) may increase global poverty risk? A cloud on the horizon. Environ Res [Internet]. 2020;187:109668. Available from: https://www.sciencedirect.com/science/article/pii/S0013935120305612

48. Lassale C, Gaye B, Hamer M, Gale CR, Batty GD. Ethnic disparities in hospitalisation for COVID-19 in England: The role of socioeconomic factors, mental health, and inflammatory and pro-inflammatory factors in a community-based cohort study. Brain Behav Immun [Internet]. 2020;88:44-9. Available from: https://www.sciencedirect.com/science/article/pii/S0889159120311016

49. Coccia M. Factors determining the diffusion of COVID-19 and suggested strategy to prevent future accelerated viral infectivity similar to COVID. Sci Total Environ [Internet]. 2020;729:138474. Available from: https://www.sciencedirect.com/science/article/pii/S0048969720319872

50. Cooper BS, Pitman RJ, Edmunds WJ, Gay NJ. Delaying the International Spread of Pandemic Influenza. Sepulveda-Amor J, editor. PLoS Med [Internet]. 2006 May 2;3(6):e212. Available from: https://dx.plos.org/10.1371/journal.pmed.0030212

51. Kucharski AJ, Camacho A, Checchi F, Waldman R, Grais RF, Cabrol J-C, et al. Evaluation of the Benefits and Risks of Introducing Ebola Community Care Centers, Sierra Leone. Emerg Infect Dis [Internet]. 2015 Mar;21(3):393-9. Available from: http://wwwnc.cdc.gov/eid/article/21/3/14-1892_article.htm

\section{Figures}




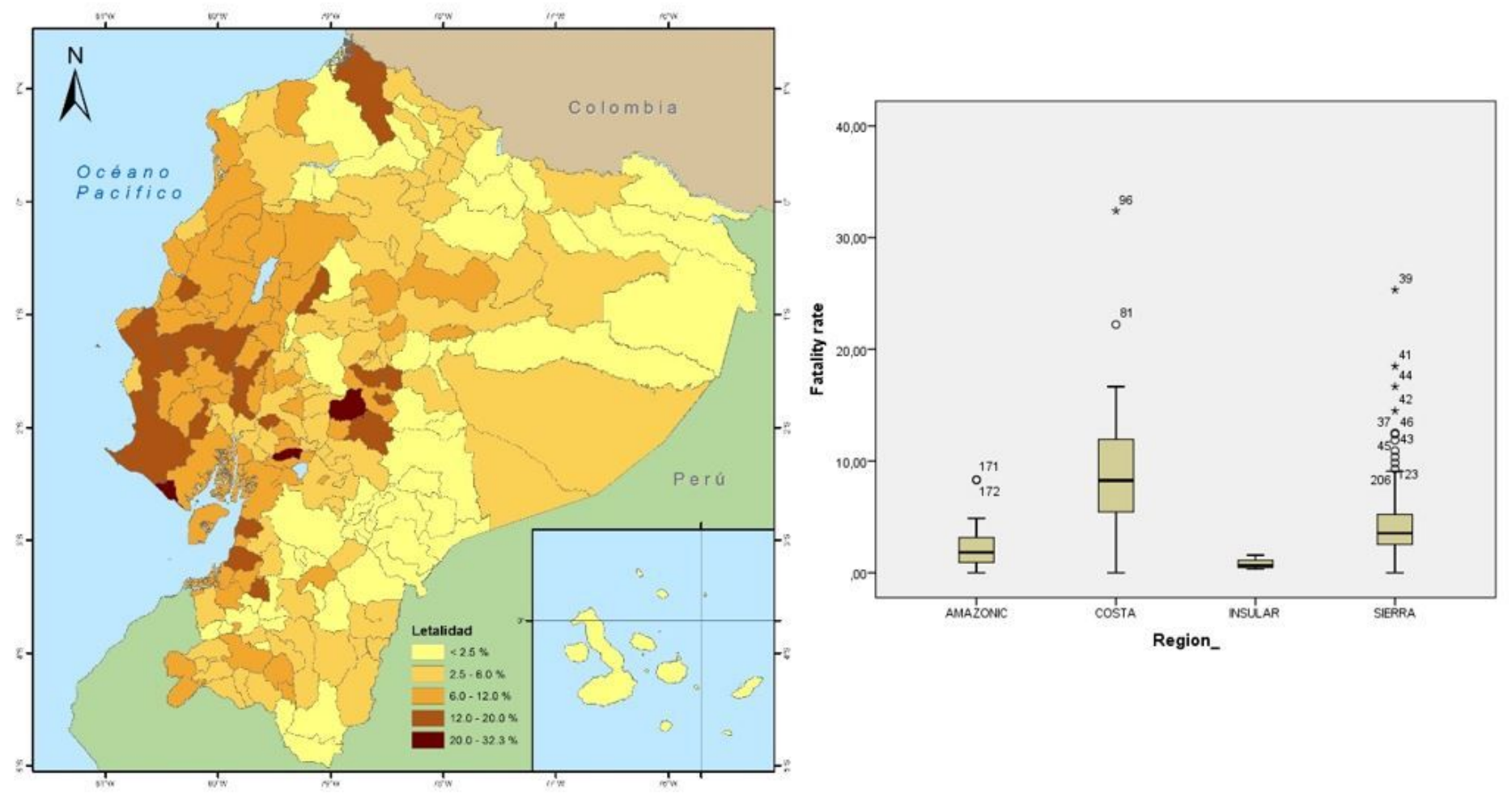

\section{Figure 1}

Case Fatality rate distribution Note: The designations employed and the presentation of the material on this map do not imply the expression of any opinion whatsoever on the part of Research Square concerning the legal status of any country, territory, city or area or of its authorities, or concerning the delimitation of its frontiers or boundaries. This map has been provided by the authors.
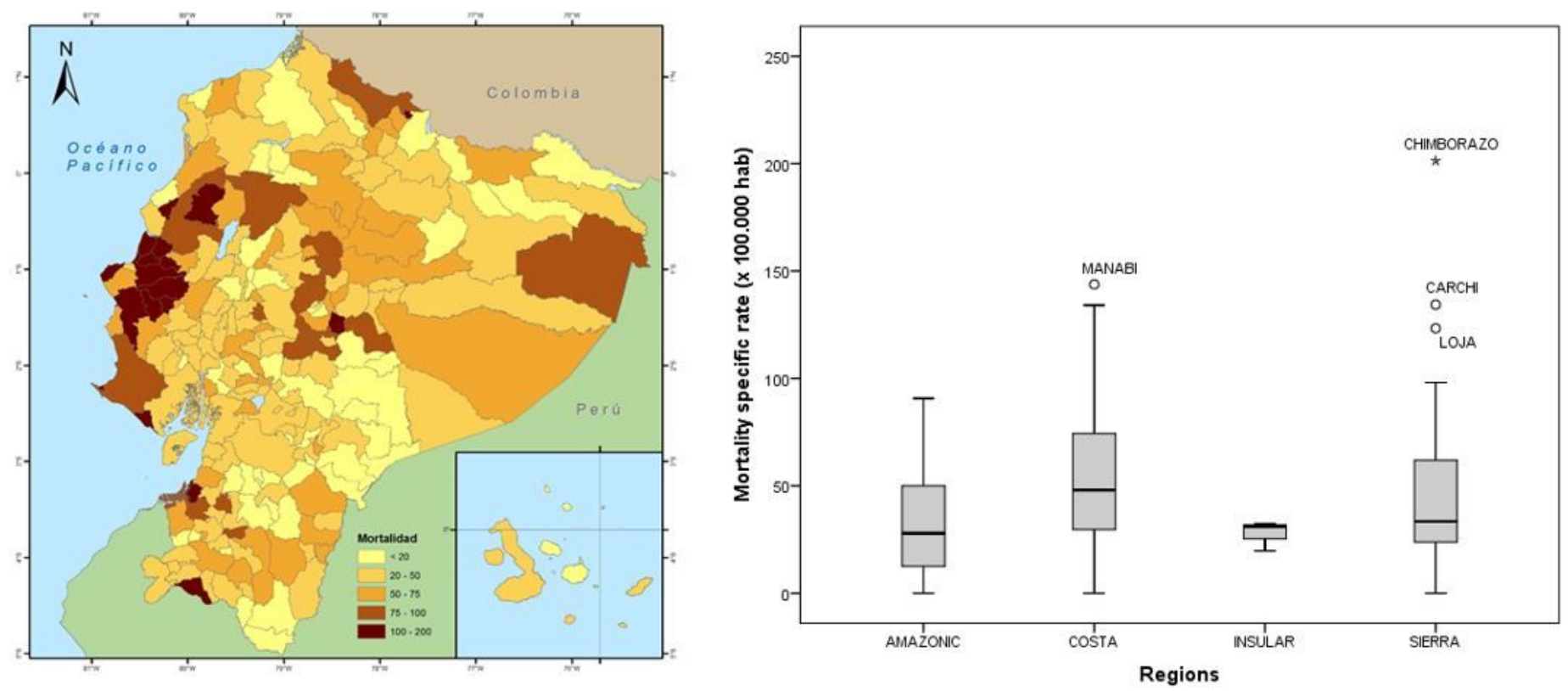

Figure 2

Crude death rate Note: The designations employed and the presentation of the material on this map do not imply the expression of any opinion whatsoever on the part of Research Square concerning the legal status of any country, territory, city or area or of its 
authorities, or concerning the delimitation of its frontiers or boundaries. This map has been provided by the authors.

Page 14/14 